\title{
Nutritional Evaluation of Predominant Tree Fodders and Shrubs of Southern Kerala as a Quality Livestock Feed
}

\author{
P. Mubeena, Usha C. Thomas, Deepa Surendran ${ }^{1}$
}

10.18805/ag.D-5388

\begin{abstract}
Background: India ranks first in global livestock production and it is an important subsidiary enterprise that support more than 75 per cent of the rural community. But fodder production is not well practiced in our country and animals generally consume naturally grown grasses and shrubs which are of low quality in terms of protein and available energy. Hence, there is an urgent need to look for new fodder resources that are sustainable in nature and cover our fodder deficit. Keeping the above in view, the present study has been proposed to evaluate the predominant tree fodders and shrubs of Southern Kerala as a quality livestock feed.

Methods: The study was conducted in College of Agriculture, Vellayani, Thiruvananthapuram during January-September, 2020 to assess the nutritional value of predominant tree fodders and shrubs in Southern Kerala as a quality feed for cattle. Ten different fodder trees and shrubs that locally fed to the cattle viz., Agathi (Sesbania grandiflora), erythrina (Erythrina indica), Drumstick (Moringa oleifera), Coconut (Cocos nucifera), Glyricidia (Glyricidia maculate), Matti (Terminalia elliptica), Subabul (Leucaena leucocephala), Cassava (Manihot esculenta), Banana (Musa acuminate) and Mango (Mangifera indica) were selected and analysed for proximate composition, crude fiber and mineral status.

Result: The result revealed that mean values for dry matter, crude protein, crude fiber, ether extract and total ash in tree fodders were $37.07 \pm 4.02,18.52 \pm 1.72,18.56 \pm 2.07,4.68 \pm 0.51,8.72 \pm 0.66$, respectively. The study also proved that Sesbania grandiflora (Agathi) is nutritionally superior to other tree fodders with high crude protein $(25.24 \%)$ and lower crude fiber $(8.43 \%)$ content. The Neutral Detergent Fiber content of fodder tree leaves varied from 17.34- 65.32 per cent and that of Acid Detergent Fiber from 11.10-48.69 per cent. Phosphorus and potassium status of top feeds comes under the range of 0.26-0.93 per cent and 1.0-2.7 per cent respectively. However the highest amount of Calcium as well as magnesium was found in Moringa oleifera ( 2.75 and 0.60 per cent respectively).
\end{abstract}

Key words: Acid detergent fiber, Crude fiber, Neutral detergent fiber, Proximate composition, Tree fodder.

\section{INTRODUCTION}

Livestock production is the backbone of Indian agriculture and plays a key role in providing employment especially in rural areas. Fodders as a group of crops differ from food and commercial crops as they are primarily grown for the fresh green vegetative biomass. India has 15 per cent of world cattle population and there is tremendous pressure of livestock on available feed and fodder, as land available for fodder production has been decreasing. Presently, it is estimated that only 4.4 per cent of the total cropped area is devoted to fodder production. Feed and fodder constitute about 60-70 per cent of the cost of milk production. Thus cultivated fodder has an important role in meeting requirement of various nutrients including roughages for livestock in our country to produce milk and it is more economical when compared to concentrates.

Dairy production is an important subsidiary and complimentary farming activity widely adopted in Kerala especially as a part of homestead farming system. The livestock census data from 1996 to 2007 showed a drastic reduction in population from 3.4 million to 1.74 million (GOK, 2011). The major factor attributed to the drastic decline in cattle population include scarcity of cheap and quality fodder, rapid increase in the price of feed and feed ingredients, diminishing grazing land and urbanization. Among these,
Department of Agronomy, College of Agriculture, Vellayani, Thiruvananthapuram-695 522, Kerala, India.

${ }^{1}$ Krishi Vigyan Kendra, Ambalavayal, Wayanad-673 593, Kerala, India.

Corresponding Author: P. Mubeena, Department of Agronomy, College of Agriculture, Vellayani, Thiruvananthapuram-695 522, Kerala, India. Email: mubeenap94@gmail.com

How to cite this article: Mubeena, P., Thomas, U.C. and Surendran, D. (). Nutritional Evaluation of Predominant Tree Fodders and Shrubs of Southern Kerala as A Quality Livestock Feed. Agricultural Science Digest. DOI: 10.18805/ag.D-5388.

Submitted: $25-05-2021 \quad$ Accepted: 03-08-2021 Online: 21-08-2021

availability of cheap and quality feed is a major issue. Availability of land for fodder cultivation is very low due to fragmentation and shift in cropping pattern from food crops to cash crops. It is estimated that the present fodder availability in Kerala from all sources together is only 5.1 million tonnes where the total requirement is 23.2 million tonnes (Anita et al., 2011)

Fodder trees and shrubs represent a potential source of protein for ruminants in the tropics. But these feed resources have been generally ignored in feeding systems for ruminants, mainly because of inadequate knowledge on nutritional quality of fodder (Devendra, 1990). In difficult 
environmental conditions, where the available grazing is not sufficient to meet the maintenance requirements of animals, the contribution from trees and shrubs is significant. Tree fodders contain high levels of crude protein and minerals and many show high levels of digestibility. They are readily accepted by livestock and presumably because of their deep-root systems, they continue to produce well into the dry season (Khan et al., 2014). Tree fodder can play a vital role in mitigating the fodder shortage in the country, as over 60 per cent of the fodder requirements of goats are normally met from shrubs, tree leaves, weeds etc (Ally and Kunjikutty, 2000).

The present study was therefore undertaken to explore nutrient contents of ten fodder tree leaves and shrubs available in the southern Kerala consumed by ruminants. The experimental foliage species were selected because they are abundantly available and highly preferred by ruminants in its natural habitat and because farmers strongly believe that these foliage species are highly nutritious.

\section{MATERIALS AND METHODS \\ Study site}

The experiment was conducted in College of Agriculture, Vellayani, Thiruvananthapuram during January-September, 2020 to assess the nutritional value of predominant tree fodders and shrubs in Southern Kerala including Thiruvananthapuram, Kollam, Pathanamthitta, Kottayam and Alappuzha. The study area located within $8.52^{\circ}$ and $9.59^{\circ}$ north latitudes and $76.93^{\circ}$ and $76.52^{\circ}$ east longitudes and average precipitation varies from $2250-2500 \mathrm{~mm}$ annually.

\section{Sample collection}

Samples were collected from southern districts of Kerala which include Thiruvananthapuram, Kollam, Pathanamthitta, Kottayam and Alappuzha. Ten different fodder trees and shrubs leaves that locally fed to the cattles were selected viz Agathi (Sesbania grandiflora), Erythrina (Erythrina indica), Drumstick (Moringa oleifera), Coconut (Cocos nucifera), Glyricidia (Glyricidia maculata), Matti (Terminalia elliptica), Subabul (Leucaena leucocephala), Cassava (Manihot esculenta), Banana (Musa acuminate) and Mango (Mangifera indica). The green leaves were rinsed in distilled water to remove dust and stored in a refrigerator to be freeze dried as soon as possible after collection. All the foliages were cut into small pieces so as to facilitate easy handling and uniform sampling for analysis. Samples were initially sun dried followed by drying in the hot air oven at $65^{\circ} \mathrm{C}$ for $24 \mathrm{hrs}$. Samples were ground to pass through $0.5 \mathrm{~mm}$ sieve and stored in zip lock bags at room temperature.

\section{Proximate analysis of tree fodders}

Proximate composition such as crude protein (CP), ether extract (EE), crude fibre (CF) and total ash (TA) were analysed by standard methods (AOAC, 2012). The fibre fractions viz. Neutral detergent fiber, (NDF) and Acid detergent fiber (ADF) were determined by Van Soest et al.
(1991). Dry matter content was calculated by drying the sample at $60^{\circ} \mathrm{C}$ in hot air oven till the constant weight. The phosphorus content of the samples were analysed calorimetrically by Vanado-Molybdate yellow colour method using spectrophotometer and potassium by flame photometric method. The magnesium and calcium content in plant samples were estimated using Atomic absorption spectrophotometry (Jackson, 1973).

\section{RESULTS AND DISCUSSION} Proximate analysis

The suitability of indigenous tree leaves as fodder is mainly decided by the proximate composition values and fiber fraction analysis. The proximate composition of different tree fodder leaves indicated in Table 1.

The actual amount of feed material leaving water and volatile acid is referred as Dry Matter (DM). The investigation on various tree fodders for DM content revealed that, the value varied from 25.8 per cent (Musa acuminata) to 66.14 per cent (Cocos nucifera) and the mean was $37.07 \pm 4.02$. The crude protein (CP) content of fodder tree leaves varied from 11.9 to 25.24 per cent with a mean value of $18.20 \pm 1.54$. The highest CP was observed for Sesbania grandiflora (25.24\%) followed by Leucaena leucocephala (24.42\%). Musa acuminata had recorded the lowest value $(11.91 \%)$.These results were in line with the findings of Gaikwad et al.(2017). The variation in CP among different tree leaves perhaps due to differential protein accumulation in the leaves during different stages of the growth of leaves. Similar results were noticed by Chandra and Mali (2014) and Cheema et al. (2014).

Alam and Djajanigra (1994) opined that, a feed with less than 10 per cent CP may adversely affect the rumen degradation. However, in the present study, CP value of all the tree leaves were found to be more than 10 per cent and it indicates that these leaves are potential source of protein and can be used as a good protein supplement to cattle by substituting costly concentrate protein supplying feed stuffs like Groundnut oil cake, Gingelly oil cake etc (Chithra, 2018).

Highest crude fat (Ether extract) content was observed in Moringa oleifera (7.39\%) followed by Manihot esculenta (6.79\%) and Glyricidia sepium (5.44\%). Among ten different tree fodders, Terminalia elliptica (2.83\%) and Cocos nucifera $(2.98 \%)$ had recorded the lower crude fat content. These results were in agreement with the findings of Gunasekaran et al. (2017) and Gomez and Valdivieso (1985). Whereas crude fiber content in the sample varied from 8.43 to 30 per cent. The highest value observed in Cocos nucifera (30\%) followed by Musa acuminata (23.78\%) and Mangifera indica (22.1\%). Since high CP and low fiber content make the best feed for cattle, in this study it was revealed that Sesbania grandiflora (Agathi) is nutritionally superior to other tree fodders with high CP (25.24\%) and lower CF $(8.43 \%)$ content.

The present study revealed that the total ash content of the selected fodder leaf sample varied from 5.27 to 12.78 
per cent, with a mean value of $8.72 \pm 0.66$ per cent. The highest ash content was observed in Moringa oleifera (12.78\%) followed by Mangifera indica (10.38\%) and Manihot esculenta (9.23\%). The Nitrogen Free Extract (NFE) of the sample determines the soluble carbohydrates and other digestible and easily utilizable non-nitrogenous substances in the feed. It was noticed that mean NFE content of sample as $45.96 \pm 2.70$ per cent. However, the highest value was noted in Terminalia elliptica (64.72\%) and the lowest for Moringa oleifera (36.36\%). The results on the chemical composition of top tree fodders revealed that the values obtained in the present study were in general agreement with those reported by other workers in this regard (Thomas, 1973; Gomez and Valdivieso, 1985; Ally and Kunjikutty, 2000)

\section{Crude fiber analysis}

Ruminants such as cattle, goat and sheep have a specialised digestive system in which the stomach is compartmentalized into four sections, which enables them to regurgitate their cud. The crude fiber analysis is a good indicator for predicting nutritional worth of fibrous feed resources, because, the intake and digestibility of forages is largely influenced by the fibre content especially Neutral detergent fibre (NDF) and Acid detergent fiber (ADF) (Harper and McNeill, 2015).

NDF value is a good indicator of the bulkiness of forage and used to calculate the amount of forage intake by the animal. Increase in NDF value generally decreases the dry matter intake by the animals. Whereas ADF content of fodder leaves indicates the potential production of energy. High ADF content in a feed indicates a reduced energy, i.e., reduced quality (Chithra, 2018).

The present study revealed that the NDF value of fodder tree leaves varied from 17.34 to 65.32 per cent with a mean value of $42.23 \pm 5.12$ per cent (Table 2). The highest NDF value was observed in Musa acuminata (65.32\%) followed by Cocosnucifera (63.09\%) and Erythrina indica (49.14\%). The lowest value noticed in Terminaliaelliptica (17.34\%). Fodder with low NDF content generally has higher ruminant feed intakes, higher production performance and rumen health, thus low NDF value is desired (Harper and McNeill, 2015). Among ten different top feeds, it was observed that Coco snucifera has higher ADF content of 48.69 per cent, followed by Musa acuminata (37.72\%). Whereas the lowest content of ADF was observed in Sesbania grandiflora $(11.10 \%)$. Since ADF values are inversely related to

Table 1: Proximate composition locally available tree leaves and shrubs commonly fed to livestock (\% on DM basis)*.

\begin{tabular}{|c|c|c|c|c|c|c|}
\hline Tree fodder & DM & $\mathrm{CP}$ & $\mathrm{EE}$ (Crude fat) & $\mathrm{CF}$ & Total ash & NFE \\
\hline $\mathrm{T}_{1}$ : Agathi (Sesbania grandiflora) & 38.24 & 25.24 & 4.47 & 8.43 & 9.2 & 45.19 \\
\hline $\mathrm{T}_{2}:$ Erythrina (Erythrina indica) & 32.53 & 22.74 & 4.27 & 21.87 & 8.51 & 37.61 \\
\hline $\mathrm{T}_{3}:$ Drumstick (Moringa oleifera) & 27.8 & 18.94 & 7.39 & 15.2 & 12.78 & 36.36 \\
\hline $\mathrm{T}_{4}:$ Coconut (Cocos nucifera) & 66.14 & 13.71 & 2.98 & 30.0 & 6.59 & 46.72 \\
\hline $\mathrm{T}_{5}$ : Glyricidia (Glyricidia maculata) & 22.5 & 16.08 & 5.44 & 19.52 & 8.34 & 46.62 \\
\hline $\mathrm{T}_{6}:$ Matti (Terminalia elliptica) & 32.6 & 17.03 & 2.83 & 10.15 & 5.27 & 64.72 \\
\hline $\mathrm{T}_{7}$ : Subabul (Leucaena leucocephala) & 36.5 & 24.42 & 3.39 & 19.89 & 7.23 & 41.15 \\
\hline $\mathrm{T}_{8}:$ Cassava (Manihot esculenta) & 48.5 & 19.74 & 6.79 & 14.66 & 9.23 & 39.58 \\
\hline $\mathrm{T}_{9}$ : Banana (Musa acuminata) & 25.8 & 11.91 & 5.73 & 23.78 & 9.65 & 46.93 \\
\hline $\mathrm{T}_{10}:$ Mango (Mangifera indica) & 40.12 & 12.21 & 3.51 & 22.1 & 10.38 & 54.69 \\
\hline Mean & 37.07 & 18.20 & 4.68 & 18.56 & 8.72 & 45.96 \\
\hline \pm SEm & 4.02 & 1.54 & 0.51 & 2.07 & 0.66 & 2.70 \\
\hline
\end{tabular}

DM: Dry matter, CP: Crude Protein, EE : Ether extracts, NFE: Nitrogen free extract.

Table 2: Crude fiber analysis and mineral status of fodder trees and shrubs (\% on DM basis).

\begin{tabular}{|c|c|c|c|c|c|c|c|c|}
\hline Tree fodder & ADF & NDF & $\mathrm{P}$ & $\mathrm{K}$ & $\mathrm{Ca}$ & $\mathrm{Mg}$ & $\mathrm{Ca} / \mathrm{Mg}$ & $\mathrm{K} / \mathrm{Ca}$ \\
\hline $\mathrm{T}_{1}$ : Agathi (Sesbania grandiflora) & 11.10 & 17.54 & 0.87 & 2.45 & 1.39 & 0.54 & 2.57 & 1.76 \\
\hline $\mathrm{T}_{2}$ : Erythrina (Erythrina indica) & 29.39 & 49.14 & 0.91 & 1.10 & 1.73 & 0.48 & 3.60 & 0.64 \\
\hline $\mathrm{T}_{3}:$ Drumstick (Moringa oleifera) & 21.39 & 34.74 & 0.78 & 2.55 & 2.75 & 0.60 & 4.58 & 0.93 \\
\hline $\mathrm{T}_{4}:$ Coconut (Cocos nucifera) & 48.69 & 63.09 & 0.49 & 1.45 & 1.32 & 0.24 & 5.50 & 1.10 \\
\hline $\mathrm{T}_{5}$ : Glyricidia (Glyricidia maculata) & 38.64 & 48.7 & 0.26 & 1.45 & 1.05 & 0.42 & 2.50 & 1.38 \\
\hline $\mathrm{T}_{6}:$ Matti (Terminalia elliptica) & 16.97 & 17.34 & 0.53 & 1.30 & 1.32 & 0.34 & 3.88 & 0.98 \\
\hline $\mathrm{T}_{7}$ : Subabul (Leucaena leucocephala)27.65 & 44.87 & 0.93 & 2.15 & 2.02 & 0.36 & 5.61 & 1.06 & \\
\hline $\mathrm{T}_{8}$ : Cassava (Manihote sculenta) & 22.32 & 42.13 & 0.88 & 2.20 & 1.53 & 0.42 & 3.64 & 1.44 \\
\hline $\mathrm{T}_{9}$ : Banana (Musa acuminata) & 37.72 & 65.32 & 0.78 & 2.70 & 1.09 & 0.48 & 2.27 & 2.48 \\
\hline $\mathrm{T}_{10}:$ Mango (Mangifera indica) & 33.63 & 39.39 & 0.62 & 1.00 & 1.36 & 0.54 & 2.52 & 0.74 \\
\hline Mean & 28.75 & 42.23 & 0.71 & 1.84 & 1.56 & 0.44 & 3.67 & 1.25 \\
\hline \pm SEm & 3.57 & 5.12 & 0.07 & 0.20 & 0.16 & 0.03 & 0.39 & 0.17 \\
\hline
\end{tabular}

NDF: Neutral detergent fiber, ADF: Acid detergent fiber. 
digestibility, forages with low ADF concentrations usually have higher energy content.

\section{Mineral status}

Farm animals require sufficient quantity of feed and fodder that could effectively meet their demands for energy, fats, proteins, minerals and vitamins. Among these nutrients, minerals play a vital role in maintaining normal growth, development and reproduction. They also protect the structural components of the body as well as maintain osmotic pressure and solute balance. Minerals have an indispensable role in the metabolism of enzymes, hormones and vitamins. Moreover, macro nutrients like calcium (Ca) and phosphorus (P) works conjointly and have important role in bone development. Apart from this, $\mathrm{Ca}$ has a crucial role in muscle function whereas Phosphorus regulates the metabolic function throughout the body. Magnesium has an inevitable role in nervous system function as well as carbohydrate metabolism and Potassium regulates osmotic pressure and transport nutrients in and out of cells.

The mineral status of feeds and fodder mainly depends upon the cropping pattern, soil type, rainfall and feeding system of that particular region of the country (Bhanderi et al., 2014). In India, these above mentioned parameters vary with different agro-climatic zones. Thus, deficiency and surplus of a particular mineral is area specific (Garg et al., 2005). The macro mineral status ( $\mathrm{P}, \mathrm{K}, \mathrm{Ca}$ and $\mathrm{Mg}$ ) of the fodder tree leaves is given in the Table 2. It was observed that highest phosphorus $(P)$ content was found in Leucaena leucocephala $(0.93 \%)$ followed by Erythrina indica $(0.91 \%)$ and Manihot esculenta $(0.88 \%)$. Whereas the lowest Phosphorus status was found in Cocos nucifera $(0.49 \%)$. Potassium status of all the top feed comes under the range of 1.0 to 2.70 per cent with highest value noticed in Musa acuminate (2.70\%) followed by Moringaoleifera (2.55\%) and Sesbania grandiflora (2.45\%). However highest Calcium (Ca) as well as Magnesium (Mg) were found in Moringa oleifera (2.75 and 0.60 per cent respectively).

Higher levels of magnesium resulted in a significant decrease in the $\mathrm{Ca}$ : $\mathrm{Mg}$ ratio and that of higher levels of $\mathrm{Ca}$, will lower the $\mathrm{K}: \mathrm{Ca}$ ratio in the plant. Hence, in this study, fodder with highest $\mathrm{Ca}$ : $\mathrm{Mg}$ ratio was found in Leucaena leucocephala (5.61) followed by Cocosnucifera (5.50). Even though Musa acuminate showed lowest Ca:Mg ratio (2.27), but highest $\mathrm{K}: \mathrm{Ca}$ ratio of 2.48 . These results were in line with the finding of Gaikwad et al., 2017; Mondal et al., 2016; and Bhanderi et al., 2014.

\section{CONCLUSION}

The present investigation on nutritional evaluation of predominant tree fodders and shrubs in Southern Kerala as a quality feed for livestock have revealed that Agathi (Sesbania grandiflora) is nutritionally superior to other tree fodders with high crude protein and lower crude fiber and ADF. Nevertheless, all the ten different top tree fodders are very good source of nutrient (protein, fiber and minerals) and can be used for livestock feeding in scarcity zones of Kerala.

\section{REFERENCES}

Alam, M.P. and Djajanigara, A. (1994). Nutritive value and yield of potential tree leaves and shrubs in Bangladesh. Proc. $7^{\text {th }}$ AAAP Animal Science Congress on Sustainable Animal Production and Environment. Bali, Indonesia. 317-318.

Ally, K. and Kunjikutty, N. (2000). Studies on tannin contents of locally available tree leaves commonly fed to goats in Kerala. Journal of Veterinary and Animal Sciences. 31: 1-4.

Anita, M.R., Lakshmi, S. and Satyanarayana, T. (2011). Guinea grass flora under varying tree shade levels and potassium. Better Crops. 5(1): 26-27.

AOAC. (2012). Official methods of Analysis (19 th $^{\text {th }}$ ). Association of Official Analytical Chemist. Washington D.C.

Bhanderi, B.M., Garg, M.R. and Sherasia, P.L. (2014). Mineral Status of Feeds, Fodder and Dairy Animals in Jalgaon District of Maharashtra State. Scholars Journal of Agriculture and Veterinary Science. 1(4A): 222-226.

Chandra, J. and Mali, M.C. (2014). Nutritional evaluation of top five fodder tree leaves of mimosaceae family of arid region of Rajesthan. Interntional Journal innovative Research and Review. 2 (1): 14-16.

Cheema, U.B. Sultan, J.I., Javaid, A., Mustafa, M.I. and Younas, M. (2014). Screening of fodder tree leaves by chemical composition, mineral profile, anti nutritional factors and in sacco digestion. Journal of Agricultural Science. 11: 558-564.

Chitra, P. (2018). Nutritive value of leguminous tree leaves as a protein source for ruminant Feed. International Journal of Livestock Research. 8 (7): 275-280.

Devendra, C. (1983). Small farm systems combining crops with livestock. Proceedings V World Conference on Animal Production, Tokyo, Japan. 1: 173-191.

Gaikwad, Pawar, A.B., Kadlag, A.D. (2017). Nutritional Status of Fodder Tree Leaves and Shrubs of Scarcity Zone of Maharashtrai U.S. National agricultural Research Project, Zonal Agricultural Research Station, Solapur (M.S.), India Advances in Life Sciences. 7(1): 11-14.

Garg, M.R., Bhanderi, B.M., Sherasia, P.L. (2005). Assessment of adequacy of macro and micro mineral content of feedstuffs for dairy animals in semi arid zone of Rajasthan. Animal Nutrition and Feed Technology. 5: 9-20.

GOK [Government of Kerala]. (2011). Economic Review (2011) [online]. Available: http://spb.kerala.gov.in/images/er/ er11/index.html [6 Jan. 2021].

Gomez, G. and Valdivieso, M. (1985).Cassava Foliage: Chemical Composition, Cyanide Content and Effect of Drying on Cyanide Elimination. Journal of the Science of Food and Agriculture. 36: 433-441.

Gunasekaran, S., Bandeswaran, C., Valli, C. and Gopi, H. (2017). Effect of feeding gliricidiasepium leaves from silvipasture model of agroforestry in degraded wastelands on milk yield and Its composition in milch cows. International Journal Current Microbiology and Applied Science. 6(10): 2420-2423. 
Harper, J. and McNeill, M.D. (2015). The role iNDF in the regulation of feed intake and the importance of its assessment in subtropical ruminant systems (The Role of iNDF in the Regulation of Forage Intake). Agriculture. 5: 778-790.

Jackson, M.L. (1973). Soil Chemical Analysis. Prentice Hall of India. Pvt. Ltd. New Delhi, 498p.

Khan, S. Khan, S., Anwar, K., Kalim, K., Saeed, A., Shah, S., Safirullah, Ahmad, Z. and Ikram, M.H. (2014). Nutritional evaluation of some top fodder tree leaves and shrubs of district Dir (lower), Pakistan as a quality livestock feed. International Journal Current Microbiology and Applied Science. 3(5): 941-947.
Mondal, M., Pyne, S.K. and Samanta, G. (2016). Mineral status of feeds and fodder and its influence on livestock and its products in red lateritic zone of West Bengal. International Journal of Environmental and Agricultural Sciences. 2(2): 296-301.

Thomas, K.M. (1973). Nutrient composition of coconut leaves and its relationship to nut yields in Tanzania, East African Agricultural and Forestry Journal. 39(2): 170-175.

Van Soest, P.J., Robertson, J.B. and Lewis, B.A. (1991). Methods for dietary fiber, neutral detergent fiber and non starch polysaccharides in relation to animal nutrition. Journal of Dairy Science. 74: 3583-3597. 